\title{
PENGARUH BIAYA CORPORATE SOCIAL RESPONSIBILITY DAN KEBIJAKAN DIVIDEN TERHADAP NILAI PERUSAHAAN (Studi pada Perusahaan BUMN yang terdaftar di Bursa Efek Indonesia tahun 2012-2016)
}

\author{
Fithrishiyam Aulia Rasyid, \\ Willy Sri Yuliandhari, S.E.,Ak., M.M. ${ }^{2}$ \\ 1. Universitas Telkom \\ Alamat : Jalan Telekomunikasi No. 1, Bandung \\ Email : pittoyurasyid17@gmail.com \\ 2. Universitas Telkom \\ Alamat : Jalan Telekomunikasi No. 1, Bandung \\ Email : willyyuliandari@telkomuniversity.ac.id
}

\begin{abstract}
ABSTRAK
Pada umumnya, perusahaan memiliki tujuan untuk mendapatkan keuntungan yang maksimal, memakmurkan para pemilik saham atau pemilik perusahaan serta menjadikan nilai perusahaan maksimal yang terlihat pada harga sahamnya. Penelitian ini bertujuan untuk menganalisis pengaruh biaya Corporate Social Responsibility yang diukur melalui biaya kesejahteraan karyawan, biaya kemitraan, biaya bina lingkungan dan kebijakan dividen yang diukur melalui rasio Dividend Payout Ratio (DPR) terhadap nilai perusahaan yang diukur melalui rasio Tobin's Q. Jumlah sampel dalam penelitian ini sebanyak 13 perusahaan BUMN yang terdaftar di Bursa Efek Indonesia tahun 2012-2016 dengan data berdasarkan pada laporan tahunan. Metode dalam penelitian ini adalah statistik deskriptif dan regresi data panel dengan menggunakan software eviews versi 9. Teknik pemilihan sampel yang digunakan yaitu purposive sampling. Metode analisis data menggunakan analisis regresi data panel dengan signifikansi 5\%. Berdasarkan hasil penelitian, secara simultan biaya Corporate Social Responsibility dan kebijakan dividen berpengaruh terhadap nilai perusahaan sebesar 14,31\%. Sedangkan sisanya 85,69\% dipengaruhi oleh variabel lain diluar penelitian. Secara parsial, biaya Corporate Social Responsibility tidak berpengaruh dengan arah negatif terhadap nilai perusahaan. Sedangkan kebijakan dividen berpengaruh dengan arah positif terhadap nilai perusahaan.
\end{abstract}

Kata kunci: Biaya Corporate Social Responsibility, Kebijakan Dividen, Nilai Perusahaan 


\section{PENDAHULUAN}

\subsection{Latar Belakang Penelitian}

Tujuan perusahaan adalah mendapatkan keuntungan yang maksimal, memakmurkan para pemilik saham atau pemilik perusahaan serta menjadikan nilai perusahaan maksimal yang terlihat pada harga sahamnya (Hartono,2009:124; dalam Prastuti dan Sudiartha, 2016). Harga saham adalah nilai saham dalam rupiah yang terbentuk akibat terjadinya aksi pembelian dan penawaran saham di bursa efek oleh sesama anggota bursa (Ratna Hadi, 2013:79).

Nilai perusahaan dapat diukur menggunakan rasio Tobin's Q. Rasio Tobin's $\mathrm{Q}$ dinilai bisa memberikan informasi paling baik karena memasukkan semua unsur hutang dan modal perusahaan, tidak hanya saham biasa dan ekuitas namun juga seluruh aset perusahaan (Silvia Agustina, 2012). Semakin besar rasio Tobin's $Q$ menujukkan bahwa perusahaan memiliki prospek pertumbuhan yang baik. Namun pada kenyataannya, terdapat beberapa perusahaan BUMN go public yang memiliki rasio Tobin's $Q$ mengalami fluktuasi. Salah satu contohnya adalah PT Bank Negara Indonesia (Persero) Tbk.

Nilai perusahaan menggambarkan tingkat kemakmuran para pemegang saham. Untuk mempertahankannya tetap tinggi diperlukan strategi-strategi seperti melaksanakan Corporate Social Responsibility dan menetapkan kebijakan dividen.

\subsection{Identifikasi Masalah}

Nilai perusahaan merupakan persepsi investor terhadap keberhasilan suatu perusahaan yang tercermin dari harga saham. Harga saham yang tinggi dinilai investor sebagai tingkat pencapaian yang baik sehingga investor bersedia menanamkan modalnya kepada perusahaan.

Corporate Social Responsibility merupakan bentuk tanggungjawab perusahaan kepada stakeholders dengan melaksanakan kegiatan-kegiatan yang memberikan manfaat baik secara langsung maupun tidak langsung. Pelaksanaan Corporate Social Responsibility dapat meningkatkan nilai perusahaan yang dilihat dari harga saham dan laba perusahaan.

Kebijakan dividen merupakan suatu keputusan atas laba yang diperoleh apakah akan dibagikan sebagai dividen kepada investor atau menahannya sebagai laba ditahan untuk reinvestasi.

Berdasarkan perhitungan data atas tiga variabel diatas, penulis menemukan adanya kesenjangan teori. Contohnya pada PT Bank Negara Indonesia (Persero) Tbk. Di mana, biaya Corporate Social Responsibility megalami kenaikan selama 5 tahun berturut, kebijakan dividen dengan proksi DPR mengalami konstan selama 4 tahun dan naik di tahun selanjutnya. Sedangkan nilai perusahaannya dengan proksi Tobin's $Q$ mengalami konstan selama 3 tahun dan turun selama 2 tahun.

\subsection{Tujuan Penelitian}

Tujuan dari penelitian ini antara lain adalah sebagai berikut :

1. Untuk menjelaskan biaya Corporate Social Responsibility, kebijakan dividen, dan nilai perusahaan pada perusahaan BUMN yang terdaftar di Bursa Efek Indonesia tahun 2012-2016. 
2. Untuk mengetahui apakah biaya Corporate Social Responsibility dan kebijakan dividen secara simultan berpengaruh terhadap nilai perusahaan pada perusahaan BUMN yang terdaftar di Bursa Efek Indonesia tahun 2012-2016.

3. Untuk mengetahui apakah biaya Corporate Social Responsibility secara parsial berpengaruh terhadap nilai perusahaan pada perusahaan BUMN yang terdaftar di Bursa Efek Indonesia tahun 2012-2016.

4. Untuk mengetahui apakah kebijakan dividen secara parsial berpengaruh terhadap nilai perusahaan pada perusahaan BUMN yang terdaftar di Bursa Efek Indonesia tahun 2012-2016.

\subsection{Manfaat Penelitian}

1. Aspek Akademis

Penelitian ini diharapkan dapat menjadi salah satu acuan untuk penelitian selanjutnya dan dapat memberikan tambahan pemikiran dalam pengembangan ilmu pengetahuan.

2. Aspek Penulis

Diharapkan penelitian ini dapat menjadi referensi dan pembelajaran dalam pembahasan serupa yang disempurnakan.

3. Aspek Perusahaan

Penelitian ini diharapkan dapat menjadi bahan masukan untuk selalu mempertahankan dan mengembangkan Corporate Social Responsibility yang diwujudkan melalui program-program dengan melibatkan stakeholders serta menjadikan kebijakan dividen sebagai salah satu faktor dalam mengoptimalkan dan meningkatkan nilai perusahaan untuk mensejahterakan kemakmuran investor.

\section{TINJAUAN PUSTAKA}

\subsection{Dasar Teori}

\subsubsection{Corporate Social Responsibility}

Corporate Social Responsibility merupakan suatu komitmen berkelanjutan dari dunia usaha untuk bertindak etis dan memberikan kontribusi kepada pengembang ekonomi dari komunitas setempat maupun masyarakat lua (Untung, 2014:3). Corporate Social Responsibility berpijak pada triple bottom lines, yaitu profit, people, planet (John Elkington, 1997; dalam Hadi, 2011:56).

Corporate Social Responsibility diimplementasikan dalam bentuk aktivitas-aktivitas yang melibatkan stakeholders dengan mengeluarkan sejumlah biaya. Biaya yang dimaksud meliputi biaya kesejahteraan karyawan, biaya kemitraan, dan biaya bina lingkungan (Septiana dan Nur, 2012). Biaya kesejahteraan karyawan berupa tunjangan-tunjangan, kenikmatan karyawan, gaji, maupun pensiun. Biaya kemitraan berupa pemberian kredit usaha kecil, pembekalan keterampilan, pendidikan manajemen, dan lain sebagainya. Biaya bina lingkungan berupa bantuan bencana alam, bantuan sarana dan prasarana, bantuan kesehatan, bantuan sarana ibadah, dan lain sebagainya. Berdasarkan Peraturan Menteri BUMN RI Nomor PER-03/MBU/12/2016, besarnya biaya program kemitraan dan bina lingkungan bersumber dari laba bersih dengan maksimal $4 \%$ dari proyeksi laba bersih tahun sebelumnya. 


\subsubsection{Kebijakan Dividen}

Dividen adalah keuntungan bagi hasil yang diterima oleh pemegang saham dari suatu perusahaan (Musthafa, 2017:141). Kebijakan dividen merupakan keputusan untuk membagi laba yang diperoleh perusahaan kepada pemegang saham sebagai dividen atau akan menahan dalam bentuk laba ditahan untuk digunakan sebagai pembiayaan investasi pada masa yang akan datang (Mulyawan, 2015:243).

Pada umumnya, kebijakan dividen diukur menggunakan Dividend Payout Ratio (DPR). DPR adalah rasio yang mencerminkan tingkat keuntungan yang akan dibagikan perusahaan kepada pemegang saham. Semakin besar rasio DPR, maka merefleksikan kebijakan dividen yang baik (Ayuni et al, 2014). Menurut Sartono (2010:491), formula untuk perhitungannya adalah sebagai berikut:

\section{Dividend Per Share \\ DPR $=\frac{\text { Earning Per Share }}{\text { Dividend Per Share }}$}

\subsubsection{Nilai Perusahaan}

Menurut Suharli (2006) dalam Ernawati dan Widyawati (2015), menjelaskan bahwa salah satu hal yang dipertimbangkan oleh investor dalam melakukan investasi adalah nilai perusahaan dimana investor tersebut menanamkan modal. Nilai perusahaan merupakan persepsi investor terhadap tingkat keberhasilan perusahaan yang tercermin pada harga saham. Semakin tinggi harga saham, maka semakin tinggi nilai perusahaan (Brigham dan Daves, 2002; dalam Pakpahan, 2010).

Pada umumnya, nilai perusahaan dapat diukur dengan beberapa pendekatan analisis rasio, salah satunya menggunakan rasio Tobin's $Q$. Menurut Prasetyorini (2013), analisis Tobin's $Q<1$ menunjukkan bahwa nilai buku aset perusahaan lebih besar dari nilai pasar perusahaan, sehingga perusahaan akan menjadi sasaran akuisisi yang menarik baik untuk digabungkan dengan perusahaan lain atau dilikuidasi karena nilai saham dihargai rendah (undervalued). Sebaliknya, jika nilai Tobin's $Q>1$ menunjukkan bahwa nilai buku aset perusahaan lebih rendah dari nilai perusahaan, sehingga mengindikasi bahwa perusahaan memiliki potensi pertumbuhan yang tinggi karena nilai perusahaan lebih dari sekedar nilai asetnya (overvalued). Menurut Smithers dan Wright (2007:37) dalam Prasetyorini (2013), formula untuk perhitungannya adalah sebagai berikut:

\section{Tobin's $Q=$}

\section{TA}

Dimana:

MVE = Nilai pasar ekuitas (closing price $\mathrm{x}$ jumlah saham beredar)

Debt = Nilai total kewajiban perusahaan

TA $=$ Total aktiva perusahaan 


\subsection{Kerangka Pemikiran}

\subsubsection{Biaya Corporate Social Responsibility dan Nilai Perusahaan}

Tanggungjawab sosial perusahaan memiliki kandungan dan konsekuensi baik secara sosial maupun secara ekonomi. Dapat dipaparkan bahwa perusahaan dalam melakukan tanggungjawab harus dengan penuh keseriusan dan didukung oleh strategi implementasi yang tepat yang memiliki manfaat untuk meningkatkan nilai bagi masyarakat, mengurangi komplain masyarakat serta dapat membantu pemecahan persoalan yang dihadapi masyarakat baik di bidang sosial, ekonomi, lingkungan maupun kesehatan (Hadi, 2011:6). Impelementasi program Corporate Social Responsibility merupakan realisasi dan aktualiasi dari upaya perusahaan untuk terus dekat dengan masyarakat (Murdani, 2016).

Pelaksanaan Corporate Social Responsibility merupakan salah satu strategi dalam meningkatkan nilai perusahaan (Yahdiyani dan Suryono, 2017). Dalam pelaksanaannya tersebut, membutuhkan biaya yang besarannya tidak sedikit dan didasarkan pada hasil keputusan RUPS. Menurut Pratama et al (2013), semakin tinggi biaya Corporate Social Responsibility yang dikeluarkan, maka akan diikuti dengan kenaikan nilai perusahaan.

\subsubsection{Kebijakan Dividen dan Nilai Perusahaan}

Kebijakan dividen merupakan suatu kebijakan yang penting dan harus dipertimbangkan matang oleh manajemen perusahaan, karena dividen melibatkan kepentingan saham dengan dividennya dan kepentingan perusahaan dengan laba ditahannya. Pada hakikatnya, kebijakan dividen akan menentukan berapa banyak laba yang diperoleh akan dibagikan kepada pemegang saham sebagai dividen dan berapa banyak laba yang akan ditahan untuk reinvestasi (Yuliana et al, 2013). Hal ini akan mempengaruhi nilai perusahaan dan memberikan kemakmuran kepada pemegang saham. Semakin tinggi nilai kesehatan suatu perusahaan akan memberikan keyakinan kepada pemegang saham untuk mengolah pendapatan (dividend atau capital gain) di masa yang akan datang (Yunitasari dan Priyadi, 2014).

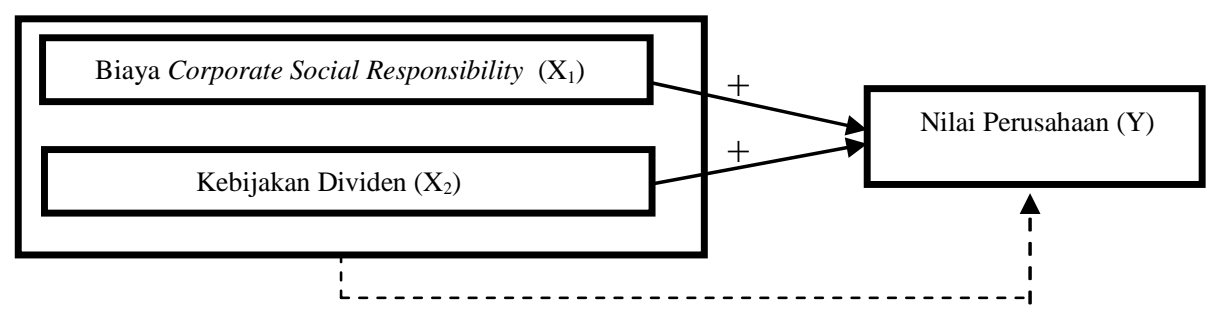

\section{METODE PENELITIAN}

\subsection{Jenis Penelitian}

Penelitian ini menggunakan metode deskriptif dan verifikatif yang sifatnya kausalitas dengan pendekatan kuantitatif. 
ISSN

2460-030X

\subsection{Teknik Pengumpulan Data}

Data yang digunakan adalah data sekunder berupa laporan tahunan Perusahaan BUMN yang terdaftar di Bursa Efek Indonesia tahun 2012-2016.

\subsection{Operasionalisasi Variabel}

Tabel 1. Operasionalisasi Variabel

\begin{tabular}{|c|c|c|c|}
\hline Variabel & Konsep Variabel & Indikator Skala & Skala \\
\hline \multicolumn{4}{|c|}{ Independen } \\
\hline $\begin{array}{l}\text { Biaya } \\
\text { Corporate } \\
\text { Social } \\
\text { Responsibility } \\
\left(\mathrm{X}_{1}\right)\end{array}$ & $\begin{array}{l}\text { Corporate Social } \\
\text { Responsibility diukur } \\
\text { dengan sejumlah biaya } \\
\text { yang dikeluarkan oleh } \\
\text { perusahaan dalam } \\
\text { pelaksanaannya } \\
\text { (Pratama et al, 2017) }\end{array}$ & $\begin{array}{c}\text { (Biaya Corporate Social } \\
\text { Responsibility = Jumlah } \\
\text { biaya kesejahteraan } \\
\text { karyawan + biaya } \\
\text { kemitraan + biaya bina } \\
\text { lingkungan) }\end{array}$ & Rasio \\
\hline $\begin{array}{l}\text { Kebijakan } \\
\text { Dividen }\left(\mathrm{X}_{2}\right)\end{array}$ & $\begin{array}{l}\text { Kebijakan dividen } \\
\text { merupakan suatu } \\
\text { kebijakan yang penting } \\
\text { dan harus } \\
\text { dipertimbangkan matang } \\
\text { oleh manajemen } \\
\text { perusahaan, karena } \\
\text { kebijakan akan } \\
\text { melibatkan kepentingan } \\
\text { saham dengan } \\
\text { dividennya (Yuliana et } \\
\text { al, 2013) }\end{array}$ & $\mathrm{DPR}=\frac{\text { Dividend Per Share }}{\text { Earning Per Share }}$ & Rasio \\
\hline \multicolumn{4}{|c|}{ Dependen } \\
\hline $\begin{array}{l}\text { Nilai } \\
\text { Perusahaan }(\mathrm{Y})\end{array}$ & $\begin{array}{l}\text { Nilai perusahaan } \\
\text { merupakan persepsi } \\
\text { investor terhadap tingkat } \\
\text { keberhasilan } \\
\text { perusahaan yang } \\
\text { tercermin pada harga } \\
\text { saham (Pakpahan, } \\
\text { 2010) }\end{array}$ & Tobin's $\mathrm{Q}=\frac{M V E+D e b t}{T A}$ & Rasio \\
\hline
\end{tabular}

\subsection{Populasi dan Sampel}

Populasi dalam penelitian ini adalah Perusahaan BUMN yang terdaftar di Bursa Efek Indonesia tahun 2012-2016. Teknik yang digunakan dalam penelitian ini adalah purposive sampling dengan kriteria sebagai berikut:

Tabel 2. Tabel Kriteria Pengambilan Sampel

\begin{tabular}{|c|l|c|}
\hline No & \multicolumn{1}{|c|}{ Keterangan } & $\begin{array}{c}\text { Total } \\
\text { Perusahaan }\end{array}$ \\
\hline 1 & $\begin{array}{l}\text { Perusahaan BUMN yang terdaftar di Bursa Efek } \\
\text { Indonesia tahun 2012-2016 }\end{array}$ & 20 \\
\hline
\end{tabular}




\begin{tabular}{|c|l|c|}
\hline 2 & $\begin{array}{l}\text { Perusahaan BUMN yang tidak konsisten listing di Bursa } \\
\text { Efek Indonesia tahun 2012-2016 }\end{array}$ & (2) \\
\hline 3 & $\begin{array}{l}\text { Perusahaan BUMN yang tidak konsisten melaporkan } \\
\text { laporan tahunan tahun 2012-2016 }\end{array}$ & (1) \\
\hline 4 & $\begin{array}{l}\text { Perusahaan BUMN yang tidak memiliki data variabel } \\
\text { lengkap yang digunakan selama tahun 2012-2016 }\end{array}$ & $(4)$ \\
\hline Total sampel satu periode & $\mathbf{1 3}$ \\
\hline Total sampel periode 2012-2016 & $\mathbf{6 5}$ \\
\hline
\end{tabular}

Berdasarkan tabel diatas diperoleh 65 data observasi yang terdiri dari 13 sampel perusahaan dengan tahun penelitian 2012-2016. Teknik analisis yang digunakan dalam penelitian ini adalah analisis statistik deskriptif dan regresi data panel dengan persamaan regresi data panel sebagai berikut:

$$
\mathrm{Y}=\beta 0+\beta 1 \mathrm{X} 1+\beta 2 \mathrm{X} 2+\varepsilon
$$

Keterangan:

$\mathrm{Y} \quad=$ Nilai Perusahaan (diproksikan dengan Tobin's Q)

BO = Konstanta

$\mathrm{X} 1=$ Biaya Corporate Social Responsibility

$\mathrm{X} 2=$ Kebijakan dividen (diproksikan dengan DPR)

$\beta 1, \beta 2=$ Koefisien regresi masing-masing variabel

$\varepsilon \quad=$ Error term

\section{HASIL PENELITIAN DAN PEMBAHASAN \\ 4.1. Analisis Statistik Deskriptif}

Tabel 3. Hasil Uji Statistik Deskriptif

\begin{tabular}{|l|c|c|c|}
\hline & Biaya CSR (Rp) & $\begin{array}{c}\text { Kebijakan } \\
\text { Dividen }\end{array}$ & Nilai Perusahaan \\
\hline Mean & $3,523,312,634,482$ & 0.3421 & 1.6981 \\
\hline Maksimum & $16,600,619,000,000$ & 0.6946 & 3.8537 \\
\hline Minimum & $120,791,804,096$ & 0.1043 & 0.8265 \\
\hline Standar Deviasi & $4,616,578,438,714$ & 0.1321 & 0.7467 \\
\hline
\end{tabular}

Sumber: Data sekunder diolah penulis (2018)

Berdasarkan tabel 3 diatas, nilai rata-rata biaya CSR pada perusahaan BUMN yang terdaftar di Bursa Efek Indonesia tahun 2012-2016 adalah sebesar Rp3,523,312,634,482. Rata-rata tersebut lebih kecil dari standar deviasi sebesar Rp4,616,578,438,714. Hal ini menunjukkan bahwa data dari variabel biaya CSR tersebut tidak berkelompok atau bervariasi, yang artinya memiliki nilai sebaran yang berbeda. Nilai maksimum Biaya CSR sebesar Rp16,600,619,000,000 dimiliki oleh PT Bank Rakyat Indonesia Tbk pada tahun 2016. Sedangkan nilai minimum sebesar Rp120,791,804,096 dimiliki oleh PT Pembangunan Perumahan (Persero) Tbk pada tahun 2012.

Berdasarkan tabel 3 diatas, nilai rata-rata kebijakan dividen dengan proksi DPR pada perusahaan BUMN yang terdaftar di Bursa Efek Indonesia tahun 2012-2016 adalah sebesar 0.3421. Rata-rata tersebut lebih besar dari standar deviasi sebesar 0.1321 . Hal ini menunjukkan bahwa data dari variabel kebijakan dividen tersebut berkelompok atau tidak bervariasi, yang artinya 
ISSN

2460-030X

memiliki nilai sebaran yang sama. Nilai maksimum dari kebijakan dividen sebesar 0.69461 dimiliki oleh PT Telekomunikasi Indonesia Tbk pada tahun 2013. Sedangkan nilai minimum dari kebijakan dividen sebesar 0.1043 dimiliki oleh PT Adhi Karya (Persero) Tbk pada tahun 2013.

Berdasarkan tabel 3 diatas, nilai rata-rata nilai perusahaan dengan proksi Tobin's Q pada perusahaan BUMN yang terdaftar di Bursa Efek Indonesia tahun 2012-2016 adalah sebesar 1.6981. Rata-rata tersebut lebih besar dari standar deviasi sebesar 0.7467 . Hal ini menunjukkan bahwa data dari variabel nilai perusahaan tersebut berkelompok atau tidak bervariasi, yang artinya memiliki nilai sebaran yang sama. Nilai maksimum nilai perusahaan dengan proksi Tobin's Q sebesar 3.8537 dimiliki oleh PT Semen Indonesia (Persero) Tbk pada tahun 2012. Sedangkan nilai minimum sebesar 0.8265 dimiliki oleh PT Timah (Persero) Tbk pada tahun 2015.

\subsection{Analisis Regresi Data Panel}

Berdasarkan hasil pengujian dengan menggunakan 2 model pendekatan yaitu uji chow dan uji hausman, maka dapat disimpulkan bahwa model random effect yang lebih baik digunakan dalam penelitian ini.

\section{Tabel 4. Hasil Uji Random Effect}

Dependent Variable: $\mathrm{Q}$

Method: Panel EGLS (Cross-section random effects)

Date: 05/15/18 Time: 15:07

Sample: 20122016

Periods included: 5

Cross-sections included: 13

Total panel (balanced) observations: 65

Swamy and Arora estimator of component variances

\begin{tabular}{crrrr}
\hline \hline Variable & Coefficient & Std. Error & t-Statistic & Prob. \\
\hline \hline C & 1.003828 & 0.292130 & 3.436243 & 0.0011 \\
BIAYACSR & $-4.74 \mathrm{E}-14$ & $2.87 \mathrm{E}-14$ & -1.648118 & 0.1044 \\
DPR & 2.517234 & 0.743851 & 3.384055 & 0.0012 \\
\hline \hline
\end{tabular}

\begin{tabular}{lccc}
\hline \hline & Effects Specification & & \\
& & S.D. & Rho \\
\hline \hline Cross-section random & 0.465681 & 0.4716 \\
Idiosyncratic random & 0.492929 & 0.5284 \\
\hline
\end{tabular}

Weighted Statistics

\begin{tabular}{llll}
\hline \hline R-squared & 0.169923 & Mean dependent var & 0.726564 \\
Adjusted R-squared & 0.143146 & S.D. dependent var & 0.527626 \\
S.E. of regression & 0.488404 & Sum squared resid & 14.78941 \\
F-statistic & 6.345925 & Durbin-Watson stat & 1.557071 \\
Prob(F-statistic) & 0.003109 & &
\end{tabular}


Sumber: Hasil Output Eviews versi 9

Berdasarkan tabel 4 diatas, penulis merumuskan persamaan model regresi data panel sebagai berikut:

Dimana:

$$
Y=1.003828-4.74 E-14 X_{1}+2.517234 X_{2}+\varepsilon
$$

$Y=$ Nilai Perusahaan (Tobin's $Q$ )

$\mathrm{X}_{1}=$ Biaya CSR

$\mathrm{X}_{2}=$ Kebijakan Dividen (DPR)

$\varepsilon=$ Error Term

Persamaan regresi diatas dapat diartikan sebagai berikut :

a. Nilai konstanta sebesar 1.003828 menunjukkan bahwa jika variabel independen pada regresi yaitu biaya CSR dan kebijakan dividen bernilai nol, maka nilai perusahaan yang dimiliki oleh Perusahaan BUMN yang terdaftar di Bursa Efek Indonesia adalah sebesar 1.003828.

b. Koefisien regresi Biaya CSR sebesar -4.74E-14 menunjukkan bahwa setiap biaya CSR tidak berpengaruh dengan arah negatif terhadap nilai perusahaan yang diproksikan dengan Tobin's Q.

c. Koefisien regresi kebijakan dividen yang diproksikan dengan DPR sebesar 2.517234 menunjukkan bahwa setiap terjadinya kenaikan nilai DPR sebesar 1 (satu) satuan dengan asumsi variabel lainnya bernilai 0 (nol), maka DPR akan mengalami kenaikan sebesar 2.517234 satuan. Hal ini menunjukkan bahwa ketika DPR meningkat maka Tobin's Q juga akan meningkat.

\subsubsection{Analisis Koefisien Determinasi $\left(\mathbf{R}^{2}\right)$}

Berdasarkan tabel 4,dapat diketahui nilai Adjusted $R$-Squared model penelitian adalah sebesar 0.143146 atau $14.31 \%$. Dengan demikian, maka variabel independen yang terdiri dari biaya CSR dan kebijakan dividen dapat mempengaruhi variabel dependen yaitu nilai perusahaan sebesar $14.31 \%$. Sedangkan $85.69 \%$ dipengaruhi oleh variabel lain diluar penelitian.

\subsubsection{Uji F (Simultan)}

Berdasarkan tabel 4, diketahui bahwa nilai prob (F-static) adalah sebesar 0.003109 atau lebih kecil dari 0.05 , maka $\mathrm{H}_{01}$ ditolak. Hal ini berarti bahwa variabel independen dalam penelitian ini, yaitu biaya CSR dan kebijakan dividen dengan proksi DPR secara simultan berpengaruh terhadap nilai perusahaan dengan proksi Tobin's Q pada Perusahaan BUMN yang terdaftar di Bursa Efek Indonesia tahun 2012-2016.

\subsubsection{Uji t (parsial)}

Berdasarkan tabel 4, diketahui bahwa:

a. Variabel biaya CSR memiliki koefisien $-4.74 \mathrm{E}-14$ dengan nilai probability sebesar $0.1044>0.05$, maka $\mathrm{H}_{02}$ diterima. Sehingga variabel biaya CSR 
ISSN

2460-030X

secara parsial tidak berpengaruh dengan arah negatif terhadap variabel nilai perusahaan dengan proksi Tobin's Q.

b. Variabel kebijakan dividen dengan proksi DPR memiliki koefisien 2.517234 dengan nilai probability sebesar $0.0012<0.05$, maka $\mathrm{H}_{03}$ ditolak. Sehingga variabel kebijakan dividen dengan proksi DPR secara parsial berpengaruh dengan arah positif terhadap variabel nilai perusahaan dengan proksi Tobin's Q.

\subsection{Pembahasan Hasil Penelitian}

\subsubsection{Pengaruh Biaya Corporate Social Responsibility terhadap Nilai Perusahaan}

Biaya Corporate Social Responsibility tidak berpengaruh terhadap nilai perusahaan. Hal ini bertentangan dengan hipotesis yang ada. Maka dapat disimpulkan bahwa jumlah pengeluaran biaya untuk melaksanakan CSR tidak akan mempengaruhi naik atau turunnya suatu nilai perusahaan.

Berdasarkan analisis statistik deskriptif, diketahui bahwa PT Bank Rakyat Indonesia merupakan perseroan yang paling besar mengeluarkan biaya untuk melaksanakan CSR dan mengalami peningkatan setiap tahunnya. Namun, jika dilihat dari nilai perusahaan, rasio Tobin's $Q$ berfluktuasi setiap tahunnya. Dimana pada tahun 2012, biaya CSR PT Bank Rakyat Indonesia (Persero) Tbk sebesar Rp8,673,449,000,000 dengan nilai rasio Tobin's Q sebesar 1.1933. Tahun 2013, biaya CSR sebesar Rp11,554,732,000,000 dengan nilai rasio Tobin's Q sebesar 1.1589. Tahun 2014, biaya CSR sebesar Rp13,000364,000,000 dengan nilai rasio Tobin's Q sebesar 1.2365. Tahun 2015, biaya CSR sebesar Rp15,109,826,000,000 dengan nilai rasio Tobin's $Q$ sebesar 1.1921. Tahun 2016, biaya CSR sebesar Rp16,600,619,000,000 dengan nilai rasio Tobin's $Q$ sebesar 1.3929.

\subsubsection{Pengaruh Kebijakan Dividen terhadap Nilai Perusahaan}

Kebijakan dividen berpengaruh terhadap nilai perusahaan. Koefisien regresi variabel kebijakan dividen proksi DPR memiliki nilai positif yaitu sebesar 2.517234 yang menunjukkan setiap peningkatan satu satuan DPR maka nilai perusahaan akan mengalami peningkatan. Hasil ini mendukung hipotesis yang dibangun peneliti.

Berdasarkan analisis statistik deskriptif, diketahui PT Telekomunikasi Indonesia (Persero) Tbk merupakan perseroan yang memiliki nilai DPR paling tinggi dibandingkan sampel lainnya selama 5 tahun yaitu sebesar 0.6518 pada tahun 2012, sebesar 0.6946 pada tahun 2013, sebesar 0.5971 pada tahun 2014, sebesar 0.5999 pada tahun 2015, dan sebesar 0.5982 pada tahun 2016 dengan nilai perusahaan yang diproksikan rasio Tobin's Q sebesar 1.9547 pada tahun 2012, sebesar 2.0265 pada tahun 2013, sebesar 2.3759 pada tahun 2014, sebesar 2.2726 pada tahun 2015, dan sebesar 2.6075 pada tahun 2016. Hal ini sejalan dengan hasil penelitian Wijaya dan Wibawa (2010), Fenandar dan Raharja (2012) dan Putra dan Lestari (2016) menyatakan bahwa kebijakan dividen berpengaruh signifikan terhadap nilai perusahaan 


\section{KESIMPULAN}

a. Berdasarkan analisis statistik deskriptif, dapat disimpulkan bahwa:

1. Nilai rata-rata biaya Corporate Social Responsibility sebesar Rp3,523,312,634,482. Biaya Corporate Social Responsibility mengalami peningkatan setiap tahunnya. Hal ini menunjukkan bahwa Perusahaan BUMN yang terdaftar di Bursa Efek Indonesia tahun 2012-2016 senantiasa menyisihkan maksimal 4\% dari laba tahun sebelumnya sebagai alokasi untuk melaksanakan Corporate Social Responsibility. Sehingga citra perusahaan dimata stakeholders dipandang baik.

2. Nilai rata-rata kebijakan dividen dengan proksi DPR sebesar 0.3421 . Hal ini berarti rasio pembayaran dividen sebesar $34 \%$ dari laba yang akan dibagikan kepada pemegang saham. Hal ini menunjukkan bahwa perusahaan BUMN yang terdaftar di Bursa Efek Indonesia mengeluarkan 34\% laba yang dimiliki untuk dibagikan kepada pemegang saham sebagai dividen.

3. Nilai rata-rata nilai perusahaan dengan proksi Tobin's $Q$ sebesar 1.6981. Hal ini menunjukkan bahwa perusahaan BUMN yang terdaftar di Bursa Efek Indonesia memiliki prospek pertumbuhan yang baik karena nilai rasio berada diatas 1. Sehingga nilai perusahaan lebih dari sekedar nilai asetnya (overvalued).

b. Berdasarkan hasil pengujian analisis regresi data panel, variabel biaya Corporate Social Responsibility dan kebijakan dividen secara simultan berpengaruh terhadap nilai perusahaan. Secara parsial, biaya Corporate Social Responsibility tidak berpengaruh dengan arah negatif terhadap nilai perusahaan. Sedangkan kebijakan dividen berpengaruh dengan arah positif terhadap nilai perusahaan.

\section{DAFTAR PUSTAKA}

Ayuni et al. (2014). Pengaruh Keputusan Pendanaan dan Kebijakan Dividen yang Mediasi Risiko Keuangan terhadap Nilai Perusahaan Manufaktur Sektor Aneka Industri yang terdaftar di BEI periode 2008-2012. Fakultas Ekonomi Universitas Riau: Pekanbaru.

Ernawati dan Widyawati. (2015). Pengaruh Profitabilitas, Leverage dan Ukuran Perusahaan Terhadap Nilai Perusahaan. Jurnal IImu \& Riset Akuntansi Vol. 4 No. 4 (2015).

Hadi, Nor. (2011). Corporate Social Responsibility. Yogyakarta: Graha IImu.

Mulyawan, Setia. (2015). Manajemen Keuangan. Bandung: Pustaka Setia.

Murdani, S., Mattalatta., dan Suharwan. (2016). Program Kemitraan dan Bina Lingkungan Corporate Social Responsibility PT. Semen Tonasa terhadap Kesejahteraan Masyarakat di Kabupaten Pangkep. Jurnal Mirai Management, Volume 1 Nomor 2, Oktober 2016.

Musthafa. (2017). Manajemen Keuangan. Yogyakarta: ANDI.

Pakpahan, Rosam. (2010). "Pengaruh Faktor-Faktor Fundamental Perusahaan dan Kebijakan Dividen terhadap Nilai Perusahaan". Jurnal Ekonomi, Keuangan, Perbankan dan Akuntansi, Vol2, No.2, HIm. 211-227. 
ISSN

Jurnal Akuntansi Bisnis dan Ekonomi

2460-030X

Volume 4 No. 2, September 2018

Prasetyorini, Bhekti. (2013). Pengaruh Ukuran Perusahaan, Leverage, Price

Earning Ratio dan Profitabilitas terhadap Nilai Perusahaan. Jurnal IImiah Manajemen Volume 1 Nomor 1 Januari 2013.

Peraturan Menteri Badan Usaha Milik Negara Republik Indonesia Nomor PER-

03/MBU/12/2016 tentang Perubahan atas Peraturan Menteri Badan Usaha Milik Negara Nomor PER-09/MBU/07/2015 tentang Program Kemitraan dan Program Bina Lingkungan Badan Usaha Milik Negara.

Ratna Hadi, Sri. (2013). Sukses Membeli Saham Tanpa Modal. Jakarta: Laskar Aksara.

Septiani, Rika Amelia dan DP, Emrinaldi Nur. (2012) Pengaruh Implementasi Corporate Social Responsibility terhadap Profitabilitas Perusahaan (Studi pada Perusahaan Manufaktur yang Listing di BEI 2007 s.d 2009). Jurnal Pekbis Vol. 4 No. 2.

Sriyana, Jaka. (2014). Metode Regresi Data Panel. Yogyakarta: Ekonisia.

Sugiyono. (2012). Metode Penelitian Kombinasi (Mixed Methods). Bandung: Alfabeta.

Sugiyono. (2013). Metode Penelitian Kuantitaif, Kualitatif dan R\&D. Bandung: Alfabeta.

Undang-Undang Republik Indonesia Nomor 40 Tahun 2007 tentang Perseroan Terbatas.

Untung, Budi. (2014). CSR Dalam Dunia Bisnis. Yogyakarta: Andi Offset

Yahdiyani dan Suryono. (2017). Pengaruh Corporate Social Responsibility, Profitabilitas, Kebijakan Dividen, Ukuran Perusahaan Terhadap Nilai Perusahaan. Jurnal IImu dan Riset Akuntansi Volume 6, Nomor 7, Juli 2017 ISSN: 2460-0585.

Yuliana., Bakar Samadi., dan Isnurhadi. (2013). Keputusan Investasi, Pendanaan, dan Dividen terhadap Nilai Perusahaan dengan Risiko Bisnis sebagai Variabel Mediasi. Jurnal Keuangan dan Perbankan, Vol.17, No.3 September 2013. 